$$
\begin{gathered}
\text { 노인장기요양보험제도 실시에 따른 노인요양시설 종사자들의 } \\
\text { 운 영환경변화 인식 } \\
\text { 최지혜 }{ }^{1}, \text { 김선희 }{ }^{2}, \text { 조경원햐 } \\
{ }^{1} \text { 웅상병원, }{ }^{2} \text { 고신대학교 사회복지학과, }{ }^{3} \text { 영산대학교 의료경영학과 }
\end{gathered}
$$

\title{
Recognition of Employees in Long-term Care Facilities on the Operating Environment Changes According to Introduction of Long-term Care Insurance
}

\author{
Jee-Hye Choi ${ }^{1}$, Sun-Hee $\mathrm{Kim}^{2}$, Kyoung-Won Cho ${ }^{3 \neq}$ \\ ${ }^{1}$ Ungsang Hospital, ${ }^{2}$ Dept. of Social Welfare, Kosin University \\ ${ }^{3}$ Dept. of Health Management, Youngsan University
}

\begin{abstract}
$<$ Abstract $>$
This paper investigated the operating environment for the representative of each agency and the facility workers on the basis of analytical result of recognition changes of the operating environment changes under the operating the long-term care insurance. It was described plans to take positive effect on the operating as follows.

The first, on the result of regression analysis, the service administrative range takes the biggest effect on the general recognition of executing the long-term care insurance off and on. The affirmative recognition of the service administrative range had the general recognition on the system be positive effect. But the operator of facility asserts that the care manager's professionalism related quality of service be strengthened. The second, on the result of regression analysis, in the financial accounting administrative it is revealed the more positive recognition it is, the more positive effects it has. From the difference verification of an operation size from operation subject, the small operation size and personal facility recognize the long term care insurance positively. On the other side the facilities where the operation size is big recognize the system negatively. The long-term care facility should rearrange a support program newly and the government needs to promote the donation activity, because it is needed to reduce the financial burden of facilities.
\end{abstract}

Key Words : Long-term Care Insurance, Long-term Care Facility, Operating Environment Change 


\section{I. 서론}

우리나라는 그동안 노인장기요양서비스를 노인 복지법에 근거하여 노인의료복지시설로 분류된 노 인요양시설과 노인전문요양시설에서 생활시설서비 스를 제공하였고, 또한 재가노인복지시설로 분류된 가정봉사원파견센터, 주간보호센터 및 단기보호센 터에서 재가서비스를 제공하였다[1][2].

기존의 노인장기요양서비스는 다음과 같은 특성 이 있다. 첫째, 사회적 서비스의 수혜대상범위가 국민기초생활보장제도 및 의료급여 수급자 등 저 소득계층으로 한정되어 그 이상의 소득계층은 개 개인이 독자적인 비용부담으로 서비스를 이용해야 했으며, 둘째, 저소득층 노인은 지방자치단체가 지 정하는 시설에 입소하였고, 일반소득 노인은 시설 운영자(공급자)와의 자유로운 계약을 통해서 서비 스를 이용하는 이원적인 방식이었다. 셋째, 제공되 는 서비스의 내용이 장기요양서비스 이외의 일반 생활 지원서비스가 상당부분 제공되는 특성을 가 졌는데 이는 기존의 노인의료복지시설이나 재가노 인복지시설이 장기요양서비스만을 제공하기 위한 시설이 아니었기 때문에 나타난 현상이라 볼 수 있다[3].

국가 및 사회에서는 이러한 시설의 운영방식 및 운영환경이 노인장기요양보험제도 도입을 계기로 크게 바뀔 것으로 예측, 제도에 대한 시범사업을 3 차례 진행하였으며, 2000년 2월부터 공식적으로 장 기요양보험제도 도입에 대한 정책적 논의가 시작 된 이래 7년 만인 2007년 4월 2일에 사회보험방식 으로 장기요양서비스를 제공하는 노인장기요양보 험법이 제정되었고, 2008년 7월 1일부터 제도가 시 행되고 있다[4].

노인장기요양보험제도는 고령이나 노인성 질병 등의 사유로 일상생활을 혼자서 수행하기 어려운 노인에게 신체활동 또는 가사활동 등을 지원하며 그 동안 가족영역에 맡겨져 왔던 치매, 중풍 등 노
인에 대한 장기간의 간병, 장기요양문제를 국가와 사회가 분담하여 장기요양서비스를 제공함으로 노 인의 삶의 질을 향상시키고 가족의 부양부담을 덜 어주기 위한 제도이다[5].

특히 간호사, 사회복지사, 요양보호사를 대상으 로 실시한 노인 장기요양보험제도 시행에 따른 전 문직 종사자의 수요를 예측한 최근의 연구 결과에 따르면, 여성의 사회진출 증가추세와 효(孝) 개념 의 변화 및 소득의 증가로 인해 요양보험 이용자 가 더욱 많이 늘어날 것으로 예측하였다[6]. 또한 장애인장기요양보장제도 1 차 시범사업의 고찰을 통한 연구 결과에 따르면, 우리나라의 장애인장기 요양보장제도를 현행하는 노인장기요양보험제도와 통합, 수정하여 '장기요양'을 국가 복지제도로서 전 국민을 대상으로 하는 수발보험 체계로 개선하는 등 노인장기요양보험제도의 강화가 필요한 것으로 나타났다[7].

따라서 노인장기요양보험제도에 대한 노인요양 시설 운영환경변화 인식을 조사 분석함으로써, 향 후 노인장기요양보험제도의 안정적 정착과 성공적 인 발전, 특히 노인요양시설의 발전과 질 높은 서 비스를 제공하기 위함에 큰 의의를 가질 수 있을 것으로 예상한다.

이에 본 논문에서는 노인장기요양보험제도 노인 요양시설에서 실질적인 집행 및 관리를 담당하는 시설종사자들의 노인요양시설 운영환경변화 인식 을 전반적인 인식, 인사관리영역 인식, 서비스관리 영역 인식, 시설환경영역 인식, 재무회계영역 인식, 정보관리 및 기타영역 인식으로 나누어 관련 담당 자들의 의견을 확인함으로써 노인장기요양보험제 도의 전면실시에 따른 안정적인 정착방안을 마련 하는 기초자료를 제공하고자 한다.

이를 위해, 첫째, 노인장기요양보험제도 및 노인 요양시설에 관해 검토한다. 둘째, 노인장기요양보 험제도 실시에 따라 노인요양시설 시설종사자의 운영환경변화 인식에 대해 조사한다. 셋째, 운영환 
경변화 인식조사를 바탕으로 노인장기요양보험제 도의 안정적인 정착 방안을 모색한다.

\section{II. 연구방법}

1. 연구문제

노인장기요양보험제도 실시 전후에 노인요양시 설 운영환경변화 인식에 영향을 주는 요인을 크게 인사관리, 서비스관리, 시설환경, 재무회계, 정보관 리영역으로 구분하였다. 설정된 구체적 연구문제는 다음과 같다.

연구문제 1. 일반적 특성(운영규모별, 운영주체 별, 직책별, 성별, 연령별, 면허별)에 따른 영역별 운영환경변화 인식은 어떠한가?

연구문제 2. 일반적 특성에 따른 전반적 인식과 영역별 인식(인사, 서비스, 시설환경, 재무회계, 정 보관리 및 기타영역)은 어떤 차이가 있는가?

연구문제 3. 노인장기요양보험에 따른 노인요양 시설 운영환경변화 전반적 인식에 영향을 미치는 요인은 무엇인가?

\section{2. 연구대상 및 자료수집 방법}

연구대상은 노인장기요양보험제도 실시에 따라 국민건강보험공단에 등록된 전국 노인요양시설 1,844 개소 중 표본집단 500 개를 임의표본추출법을 사용하여 무작위로 표본을 추출하여 각 기관의 대 표자와 시설종사자를 대상으로 시설의 운영환경을 조사하였다. 연구도구는 구조화된 설문지를 이용하 여 자기보고식 방법으로 설문조사를 실시하였다. 대상자가 시설종사자임에 맞추어 빠른 시간 내에 답할 수 있도록 핵심 되는 사항만을 구성하여 간 결하게 작성하였다.

자료수집은 2008년 12월 8일부터 2009년 1월 16
일까지 우편발송과 전자메일로 500 개의 각 기관에 이루어졌고 103 부가 회수(회수율 $20.6 \%$ )되었다. 이 중 응답 미기재 2 부를 제외한 101 부를 분석에 사 용하였다.

\section{3. 측정변수}

설문지의 구성은 <표 $1>$ 과 같다. 노인요양보험 제도의 전반적 인식 및 세부변화 인식을 조사하기 위하여 등간척도로 구성하여 설문하였으며 분석에 서 0 을 기준하여 0 보다 평균값이 크면 영역별에 대한 긍정적 인식을 가지는 것으로, 0 보다 평균값 이 작으면 부정적 인식을 의미한다 $\left(-2={ }^{\prime}\right.$ 매우 부정 적', $-1={ }^{\prime}$ 부정적', $0={ }^{\prime}$ 가치중립', $1={ }^{\prime}$ 긍정적', $2={ }^{\prime}$ 매우 긍정적').

<표 1> 설문지의 구성

\begin{tabular}{|c|c|c|}
\hline 구 분 & 설문내용 & 문항수 \\
\hline 시설현황 & $\begin{array}{l}\text { 직책, 운영규모, 성별, 연령, 면헌 } \\
\text { 종류, 시설유형, 운영주체, 전화번 } \\
\text { 호, 메일주소 }\end{array}$ & 9 \\
\hline 전반적 인식 & & 1 \\
\hline \multirow{6}{*}{$\begin{array}{l}\text { 인사관리 } \\
\text { 영역 }\end{array}$} & 종사자확보 & 6 \\
\hline & 종사자 연수교육 & 1 \\
\hline & 업무의 전문성 & 1 \\
\hline & 복리후생 & 1 \\
\hline & 근무조건 & 1 \\
\hline & 시설장과 직원의 관계 & 1 \\
\hline \multirow{6}{*}{$\begin{array}{l}\text { 서비스관리 } \\
\text { 영역 }\end{array}$} & 입소대상자 확보 & 1 \\
\hline & 병원입원율 & 1 \\
\hline & 지역사회자원 활용도 & 1 \\
\hline & 서비스 프로그램 & 1 \\
\hline & 서비스 질 관리 & 1 \\
\hline & 서비스 질 수준 & 1 \\
\hline \multirow{3}{*}{$\begin{array}{l}\text { 시설환경 } \\
\text { 영역 }\end{array}$} & 시설의 환경 & 1 \\
\hline & 시설 유지보수 & 1 \\
\hline & 관리운영비 수준 & 1 \\
\hline \multirow[t]{2}{*}{ 재무회계 } & 후원금 & 1 \\
\hline & 요양보험 수가 & 1 \\
\hline \multirow{4}{*}{$\begin{array}{l}\text { 정보관리 } \\
\text { 영역 및 } \\
\text { 기타 }\end{array}$} & 요양수가청구 & 1 \\
\hline & 시설환경·입소절차 정보공개 & 1 \\
\hline & 수입·지출 경영실적 정보공개 & 1 \\
\hline & 계 & 35 \\
\hline
\end{tabular}


1) 신뢰도 분석

선행연구를 토대로 채택된 변수에 대한 적합성 여부를 검증하기 위하여 신뢰도 검사를 크론바하 알파(Cronbach's Alpha) 값을 이용한 신뢰도 분석 을 다음의 <표 2>와 같이 실시하였다. 인사관리영 역 0.867 , 서비스관리영역 0.783 , 재무관리영역 0.769 , 정보관리 및 기타영역 0.783 으로 임계치인 0.6 을 넘어 신뢰도는 매우 높은 것으로 나타났다.

<표 2> 설문지의 신뢰도

\begin{tabular}{lcc}
\hline \multicolumn{1}{c}{ 영역별구분 } & 항목수 & Cronbach의 알파 \\
\hline \hline 인사관리 & 11 & 0.867 \\
서비스관리 & 6 & 0.783 \\
시설관리 & 2 & \\
재무관리 & 3 & 0.769 \\
정보관리 및 기타 & 3 & 0.783 \\
\hline
\end{tabular}

\section{4. 분석방법}

자료 통계분석은 SPSS(Statistical Pakage for the Social Science) 14.0 을 이용하여 일반적 특성은 빈도분석을 실시하였고[8], 운영규모, 운영주체, 직 책, 성별, 연령, 면허에 따라 노인장기요양보험제도 에 대한 전반적 인식차이를 알아보기 위하여 t-test, ANOVA 분석을 하였으며, 노인장기요양보 험에 따른 노인요양시설 운영환경변화 인식에 영 향을 미치는 요인을 알아보기 위해 회귀분석을 실 시하였다[9].

\section{III. 연구 결과}

1. 조사대상의 일반적 특성
<표 3>은 조사대상 노인요양시설의 일반적 사 항인 시설지역분포, 운영규모, 운영주체와 응답자 의 일반적 특성인 직책, 성별, 연령, 면허 등을 분 석한 결과이다.

<표 3> 조사대상의 일반적 특성

\begin{tabular}{|c|c|c|c|}
\hline & 구분 & 빈도 & 구성비(\%) \\
\hline \multirow{9}{*}{ 시설지역 } & 경기도 & 21 & 20.8 \\
\hline & 강원도 & 7 & 6.9 \\
\hline & 충청북도 & 6 & 5.9 \\
\hline & 충청남도 & 11 & 10.9 \\
\hline & 전라북도 & 5 & 5.0 \\
\hline & 전라남도 & 4 & 4.0 \\
\hline & 경상북도 & 7 & 6.9 \\
\hline & 경상남도 & 30 & 29.7 \\
\hline & 무응답 & 10 & 9.9 \\
\hline \multirow{3}{*}{ 운영규모 } & 1 30명 이하 & 46 & 45.5 \\
\hline & 31 60명 이하 & 35 & 34.7 \\
\hline & 61명 이상 & 20 & 19.8 \\
\hline \multirow{2}{*}{ 운영주체 } & 사회복지법인 & 61 & 60.4 \\
\hline & 개인 & 40 & 39.6 \\
\hline \multirow{3}{*}{ 직책 } & 원장급 & 37 & 36.6 \\
\hline & 사무국장급 & 29 & 28.7 \\
\hline & 과장급 이하 & 35 & 34.7 \\
\hline \multirow{2}{*}{ 성별 } & 남 & 47 & 46.5 \\
\hline & 여 & 54 & 53.5 \\
\hline \multirow{4}{*}{ 연령 } & 30세 이하 & 15 & 14.9 \\
\hline & 31-40세 & 34 & 33.7 \\
\hline & 41-50세 & 27 & 26.7 \\
\hline & 51세 이상 & 25 & 24.8 \\
\hline \multirow{4}{*}{ 면허 } & 사회복지사 & 85 & 84.2 \\
\hline & 요양보호사 & 7 & 6.9 \\
\hline & $\begin{array}{l}\text { 간호사 } \\
\text { (간호조무사) }\end{array}$ & 5 & 5.0 \\
\hline & 기타 & 4 & 4.0 \\
\hline
\end{tabular}

응답 시설의 지역분포는 경상남도 30 곳 $(29.7 \%)$ 으로 가장 높은 분포를 보였고, 경기도 21 곳 $(21.8 \%)$, 충청남도 11 곳 $(10.9 \%)$, 강원도와 경상북도 가 각각 7 곳 $(6.9 \%)$ 으로 동일하며, 충청북도 6 곳 $(5.9 \%)$, 전라북도 5 곳 $(5.0 \%)$, 전라남도 4 곳 $(4.0 \%)$ 의 순이며, 무응답은 10 곳 $(9.9 \%)$ 이었다. 운영규모는 1 명 이상 30 명 이하 기관이 46 곳 $(45.5 \%)$ 으로 가장 
많았으며, 31명 이상 60 명 이하 기관이 35곳 (34.7\%), 61명 이상은 20곳(19.8\%)으로 조사되었고 운영주체는 사회복지법인 61 곳 $(60.4 \%)$, 개인 40 곳 (39.6\%)으로 법인시설이 더 많음을 볼 수 있다.

총 응답자에서 직책은 원장급 37 명 $(36.6 \%)$, 과장 급 35 명(34.7\%), 사무국장급 29명(28.7\%)의 순으로 구성되어 있다. 성별은 남성 47 명 $(46.5 \%)$, 여성 54 명(53.5\%)이고, 연령은 31 세 이상 40 세 이하가 34 명 $33.7 \%)$ 로 가장 높았고, 41 세 이상 50 세 이하 27 명(26.7\%), 51세 이상 25명(24.8\%), 31세 이하 15 명 $(14.9 \%)$ 의 순으로 평균연령은 42.3 세인 것으로 나 타났다. 응답자의 자격면허로는 사회복지사가 85 명 (84.2\%)으로 가장 많았고, 요양보호사 7명 $(6.9 \%)$, 간호사(간호조무사) 5 명 $(5.0 \%)$, 기타 4 명 $(4.0 \%)$ 으로 나타났다<표 3>.

\section{2. 노인요양시설 운영환경변화 인식}

노인장기요양보험 실시에 따른 제도에 대한 전 반적 및 영역별(인사관리, 서비스관리, 시설환경, 재무회계, 정보관리 및 기타)노인요양시설 운영환 경변화 인식을 조사하기 위해 각 영역별은 변수계 산을 통하여 항목 간 평균을 낸 값을 사용하였고, 전반적 인식은 0.44 로 제도에 대한 긍정적으로 나 타났다<표 4>.

<표 4> 노인요양보험 실시에 따른 운영환경변화 전 반적 및 영역별 인식

\begin{tabular}{|c|c|c|c|}
\hline & 구 분 & 평균 & 표준편차 \\
\hline \multicolumn{2}{|c|}{ 전반적인식 } & 0.44 & 0.99 \\
\hline \multirow{5}{*}{$\begin{array}{l}\text { 염 } \\
\text { 역 } \\
\text { 별 }\end{array}$} & 인사관리 & -0.12 & 0.67 \\
\hline & 서비스관리 & 0.02 & 0.74 \\
\hline & 시설환경 & -0.23 & 0.59 \\
\hline & 재무회계 & -0.67 & 0.73 \\
\hline & 정보관리 및 기타 & 0.41 & 0.70 \\
\hline
\end{tabular}

평균>0 : 긍정적인식, 평균<0 : 부정적인식

정보관리 및 기타영역이 0.41 , 서비스관리영역이 0.02 의 순으로 긍정적이었고, 재무회계영역의 경우 -0.67 , 시설환경영역이 -0.23 , 인사관리영역 -0.12 의 순으로 제도에 대해 부정적으로 나타났다.

<표 5>는 운영환경변화 영역별 세부항목 인식 에 관한 내용을 분석한 것이다.

운영환경변화에 있어서, 인사관리영역은 요양보 호사 확보 0.23 , 시설장과 직원의 관계 0.17 , 업무 전문성이 0.13 , 종사자 연수교육은 0.10 , 사회복지 사 확보 0.04 의 순으로 제도 시행 전후변화에 대해 긍정적으로 인식하였고, 물리치료사/작업치료사 확보 -0.60 , 종사자 복리후생은 -0.38 , 간호사/간호 조무사 확보 -0.30 , 근무조건 -0.26 기타인력 확보 -0.29 , 촉탁의 확보 -0.21 의 순으로 제도 시행 전후 변화에 대해 부정적인 인식을 보였다. 서비스관리 영역은 요양서비스 질 수준의 경우 0.22 , 입소자 병원입원율은 0.17 , 요양서비스 질 관리업무 0.11 , 입소자대상자 확보가 0.02 의 순으로 제도 시행 전 후변화에 대해 긍정적으로 인식하였고, 지역사회자 원 활용도는 -0.22 , 요양서비스 프로그램 다양성이 -0.05 의 순으로 제도 시행 전후변화에 대해 부정적 으로 인식하였다. 시설환경영역은 시설의 전반적인 환경은 0.47 로 긍정적인 인식을 보이는 것으로 나 타났으나 시설 유지보수관리 기관부담은 -0.93 로 부정적 인식을 가지는 것으로 나타났다. 재무회계 영역은 후원금 비중 -0.95 , 요양보험 수가수준 -0.61 , 관리운영비수준은 -0.46 의 순으로 제도 시행 전후변화에 대해 부정적인 인식을 보이는 것으로 나타났다. 마지막으로 정보관리 및 기타 영역은 시 설환경·입소절차의 정보공개는 0.65 , 수입·지출관련 경영실적 정보공개가 0.48 , 요양수가청구관련 업무 0.10 의 순으로 노인장기요양보험제도 실시에 따른 전후변화에 대한 긍정적인 인식을 가지는 것으로 조사되었다<표 5>. 
<표 5> 운영환경변화 영역별 세부 항목 인식

\begin{tabular}{|c|c|c|c|c|}
\hline & & 구 분 & 평균 & $\begin{array}{l}\text { 표준 } \\
\text { 편차 }\end{array}$ \\
\hline & & 요양보호사 확보 & 0.23 & 1.13 \\
\hline & & 시설장과 직원의 관계 & 0.17 & 0.92 \\
\hline & & 업무 전문성 & 0.13 & 1.11 \\
\hline & & 종사자 연수교육 & 0.10 & 1.03 \\
\hline & & 사회복지사 확보 & 0.04 & 0.94 \\
\hline & $\begin{array}{l}\text { 인사 } \\
\text { 과리 }\end{array}$ & 촉탁의 확보 & -0.21 & 0.90 \\
\hline & & 근무조건 & -0.26 & 1.06 \\
\hline & & 기타인력 확보 & -0.29 & 0.94 \\
\hline & & 간호사/간호조무사 확보 & -0.30 & 1.01 \\
\hline & & 종사자 복리후생 & -0.38 & 1.17 \\
\hline & & 물리치료사/작업치료사 확보 & -0.60 & 1.03 \\
\hline 영 & & 요양서비스 질 수준 & 0.22 & 1.08 \\
\hline 역 & & 입소자 병원입원율 & 0.17 & 1.08 \\
\hline 별 & 서비스 & 요양서비스 질 관리 업무 & 0.11 & 0.99 \\
\hline & 관리 & 입소대상자 확보 & 0.02 & 1.07 \\
\hline & & 요양서비스 프로그램 다양성 & -0.05 & 0.92 \\
\hline & & 지역사회자원 활용도 & -0.22 & 0.98 \\
\hline & 시설 & 시설의 전반적인 환경 & 0.47 & 0.98 \\
\hline & 환경 & 시설 유지보수관리 기관부담 & -0.93 & 0.79 \\
\hline & & 관리운영비 수준 & -0.46 & 0.89 \\
\hline & $\begin{array}{l}\text { 재무 } \\
\text { 회계 }\end{array}$ & 요양보험 수가 수준 & -0.61 & 0.94 \\
\hline & & 후원금 비중 & -0.95 & 0.83 \\
\hline & 정보 & 시설환경 · 입소절차 정보공개 & 0.65 & 0.78 \\
\hline & $\begin{array}{c}\text { 관리 } \\
\text { 및 }\end{array}$ & 수입 · 지출관련 정보공개 & 0.48 & 0.74 \\
\hline & 기타 & 요양수가청구 업무 & 0.10 & 0.98 \\
\hline
\end{tabular}

3. 일반적 특성에 따른 운영환경변화 인식

조사대상의 일반적 특성(운영규모, 운영주체, 직 책, 성별, 연령, 면허)에 따른 각 영역별 인식도를 알아보기 위해 ANOVA 및 t-test를 통해 평균을 비교·분석 하였다.

1) 전반적 인식

운영규모와 운영주체, 직책에 따라 전반적 인식
에 통계적으로 유의한 차이가 있었고, 31 60명의 규모기관과 61명 이상 규모기관에 비해 1 30명 이 하의 규모기관에서 긍정적인 전후변화 인식을 가 지고 있는 것으로 조사되어 전반적 인식은 운영규 모가 큰 시설보다 작은 시설이 긍정적으로 인식하 는 것으로 나타났으며 $(\mathrm{p}<0.01)$, 운영주체의 경우 법인이 0.08 , 개인 0.98 로 나타나 개인이 법인보다 더 긍정적 인식을 하는 것으로 나타났다 $(\mathrm{p}<0.01)$.

직책에 있어서는 사무국장급과 과장급 이하에 비해 원장급에서 긍정적인 전후변화 인식을 가지 고 있었고 $(\mathrm{p}<0.05)$, 성별, 면허에 따른 전반적 인식 은 통계적으로 유의한 차이는 없었다<표 6>.

2) 인사관리영역 인식

운영규모와 운영주체에 따라 인사관리영역 인식 에 통계적으로 유의미한 차이가 있었고, 31 60명 및 61명 이상의 규모기관에 비해 1 30명 이하의 규모기관에서 긍정적인 전후변화 인식을 가지고 있었고, 인사관리영역 인식은 운영규모가 큰 시설 보다 작은 시설이 긍정적으로 인식하는 것으로 나 타났으며 $(\mathrm{p}<0.01)$, 운영주체의 경우 개인이 법인보 다 긍정적인 전후변화 인식을 가지고 있는 것으로 나타났다 $(\mathrm{p}<0.01)$. 직책, 성별, 연령, 면허에 따른 인사관리영역은 유의한 차이가 없었다<표 6>.

3) 서비스관리영역

운영규모와 운영주체에 따라 서비스관리영역 인 식에 통계적으로 유의미한 차이가 있었고, 운영규 모가 큰 시설보다 작은 시설이 긍정적으로 인식하 는 것으로 나타났으며 $(\mathrm{p}<0.01)$, 운영주체의 경우 법인이 -0.14 , 개인은 0.26 으로 나타나 개인이 법인 보다 긍정적인 전후변화 인식을 가지고 있는 것으 로 나타났다 $(\mathrm{p}<0.01)$. 직책과 성별, 연령과 면허에 대해서는 유의한 차이가 나타나지 않았다<표 6>. 
최지혜, 김선희, 조경원 :노인장기요양보험제도 실시에 따른 노인요양시설 종사자들의 운영환경변화 인식

<표 6> 일반적 특성에 따른 운영환경변화 인식

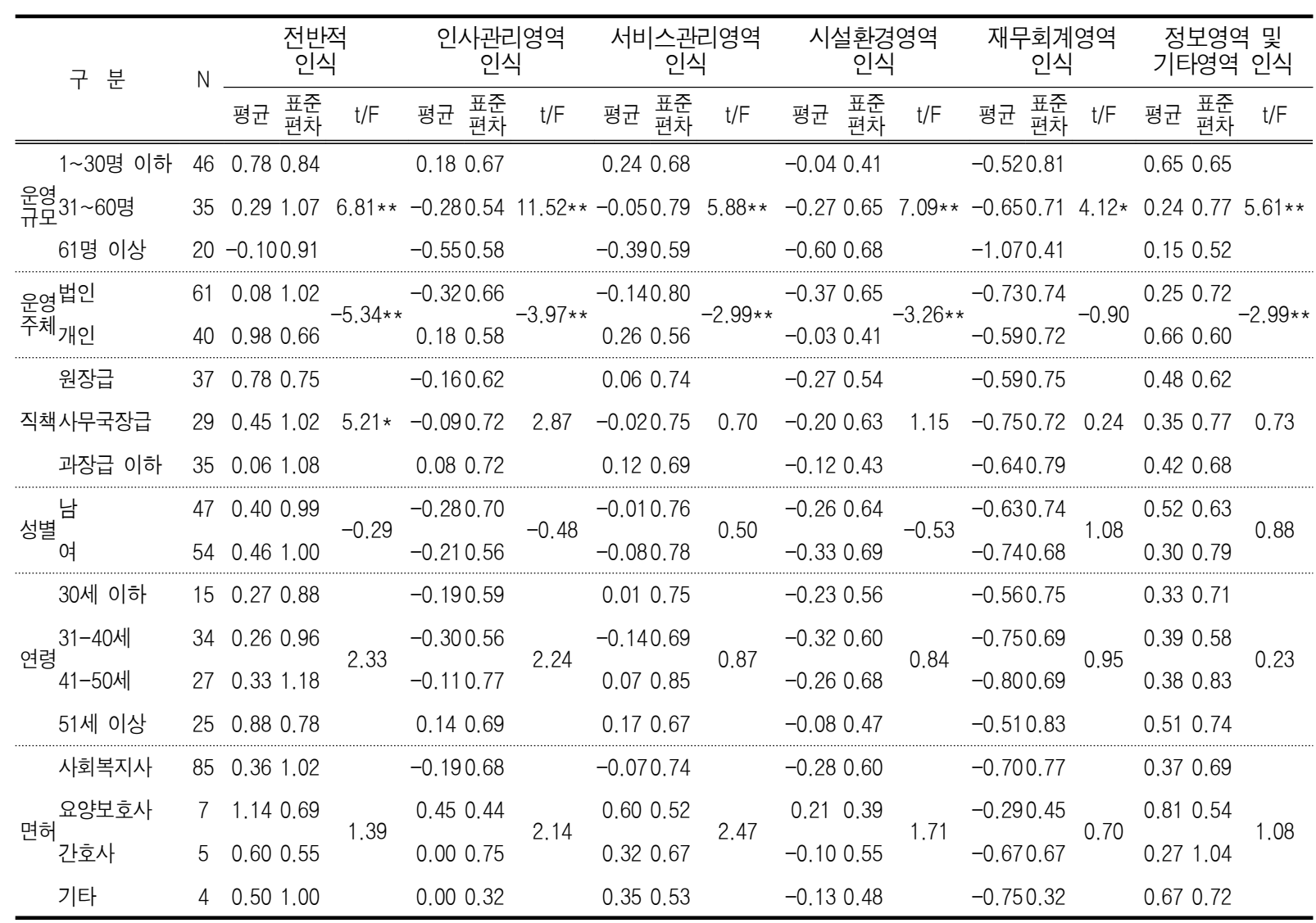

* $p<0.05, * * p<0.01$, 평균 $>0$ : 긍정적인식, 평균<0 : 부정적인식

\section{4) 시설환경영역}

운영규모와 운영주체에 따라 시설환경영역 인식 에 통계적으로 유의미한 차이가 있었고, 1 30명 이하의 규모기관에 비해 31 60명의 규모기관과 61 명 이상 규모기관이 높은 부정적인 전후변화 인식 을 가지고 있는 것으로 조사되어 운영규모가 작은 시설보다 큰 시설이 좀 더 부정적 인식을 하는 것 으로 나타났으며 $(\mathrm{p}<0.01)$, 운영주체의 경우 법인이 -0.37 , 개인은 -0.03 으로 나타나 법인이 개인보다 부정적인 전후변화 인식을 가지고 있는 것으로 나 타났다 $(p<0.01)$. 직책과 성별, 연령과 면허에 대해 서는 유의미한 차이가 나타나지 않았다<표 6>.

\section{5) 재무회계영역}

운영규모에 따라 재무회계영역 인식에 통계적으 로 유의미한 차이가 있었고, 1 30명 이하의 규모 기관에 비해 31 60명의 규모기관과 61명 이상 규 모기관이 높은 부정적인 전후변화 인식을 가지고 있는 것으로 조사되어 운영규모가 작은 시설보다 큰 시설이 부정적 인식을 하는 것으로 나타났다 $(p<0.05)$. 운영주체와 직책 및 성별, 연령과 면허에 대해서는 유의미한 차이가 나타나지 않았다<표 6>. 
6) 정보관리 및 기타영역

운영규모와 운영주체에 따라 정보관리 및 기타 영역 인식에 통계적으로 유의미한 차이가 있었고, 31 60명의 규모기관과 61명 이상 규모기관에 비해 $1 \sim 30$ 명 이하의 규모기관이 긍정적인 전후변화 인 식을 가지고 있는 것으로 조사되어 운영규모가 큰 시설보다 작은 시설이 긍정적 인식을 하는 것으로 나타났으며 $(\mathrm{p}<0.01)$, 운영주체의 경우 법인이 0.25 , 개인은 0.66 으로 나타나 개인이 법인보다 긍정적인 전후변화 인식을 가지고 있는 것으로 나타났다 $(\mathrm{p}<0.01)$. 직책과 성별, 연령과 면허에 대해서는 유 의미한 차이가 나타나지 않았다<표 6>.

4. 영역별 운영환경변화 인식이 전반적 인식 에 미치는 영향

<표 7> 운영환경변화 인식이 전반적 인식에 미치는 영향

\begin{tabular}{|c|c|c|c|c|}
\hline & \multicolumn{2}{|c|}{ 비표준화 계수 } & \multirow{2}{*}{$\begin{array}{c}\text { 표준화계수 } \\
\text { 베타 }\end{array}$} & \multirow{2}{*}{$\mathrm{t}$} \\
\hline & $B$ & 표준오차 & & \\
\hline (상수) & 0.430 & 0.212 & & 2.027 \\
\hline 운영규모 & 0.000 & 0.003 & 0.007 & 0.071 \\
\hline 운영주체(개인) & 0.498 & 0.181 & 0.250 & $2.750 * *$ \\
\hline 인사관리영역 & 0.006 & 0.171 & 0.004 & 0.035 \\
\hline 서비스관리영역 & 0.464 & 0.162 & 0.331 & $2.863 * *$ \\
\hline 시설관리영역 & 0.251 & 0.163 & 0.146 & 1.538 \\
\hline 재무회계영역 & 0.270 & 0.133 & 0.185 & $2.022 *$ \\
\hline $\begin{array}{l}\text { 정보관리 및 기 } \\
\text { 타영역 }\end{array}$ & 0.131 & 0.140 & 0.093 & 0.939 \\
\hline $\mathrm{R}^{2}$ & & & 0.542 & \\
\hline $\mathrm{F}$ & & & 14.024 & \\
\hline
\end{tabular}

<표 7>은 상관분석을 통해 밝혀 낸 요인들이 노인장기요양보험제도 실시에 따른 노인요양시설 의 운영환경변화 인식에 어떠한 영향을 미치는지 밝히기 위해 선형회귀분석을 시행한 결과이다. 분 석결과, 설명력 $\left(\mathrm{R}^{2}\right)$ 은 $54.2 \%$ 이며 $\mathrm{F}$ 값이 14.024 로 유
의확률 $\mathrm{p}<0.05$ 로 통계적으로 유의하게 나타났다.

회귀분석결과 노인장기요양보험제도 시행 후 운 영환경변화의 긍정적 인식에 영향을 미치는 것은 서비스관리영역이 $\beta=0.331$, 개인시설은 $\beta=0.250$, 재무회계영역의 경우 $\beta=0.185$ 순으로 나타났다 $(p<0.05)$. 그러나 운영규모 $\beta=0.007$, 인사관리영역 $\beta=0.004$, 시설관리영역 $\beta=0.146$, 정보관리 및 기타 영역 $\beta=0.093$ 은 전반적 인식에 통계적으로 유의하 지 않은 영향을 미치는 것으로 나타났다.

이는 서비스관리영역인 요양서비스 프로그램의 다양성과 서비스의 질 수준 향상 및 질 관리 업무 의 용이성이 노인장기요양보험제도 시행 후 시설 종사자들의 제도에 대한 전반적 인식 향상에 긍정 적 작용을 하는 것을 알 수 있으며, 재무회계관리 영역인 관리운영비의 충분한 수준과 후원의 비중 의 증가 및 요양보험 수가 인상이 제도 시행 이후 노인요양시설 운영환경변화에 대한 전반적 인식 향상에 긍정적 영향을 미치는 것을 알 수 있다.

\section{IV. 고찰}

고령화 사회에서 요구되는 다양한 노인문제와 그들의 옥구에 대응하기 위한 노인의료 복지 서비 스로써 2008년 7월 노인장기요양보험법 시행에 따 라 많은 변화들이 일어나고 있다. 특히, 본 연구자 는 노인장기요양보험제도 실시에 따른 노인요양시 설 시설종사자의 운영환경변화에 대한 변화 인식 분석 결과 다음과 같은 내용들을 파악할 수 있었 다.

첫째, 본 논문에서는 회귀분석결과, 노인장기요 양보험제도 실시 전후에 대한 전반적 인식에 서비 스관리영역이 가장 큰 영향을 미치는 것으로 나타 났다. 즉, 서비스관리영역에 대한 긍정적 인식이 제도에 대한 전반적 인식을 긍정적으로 나타나게 하는 것이다. 이는 첫째, 서비스관리영역의 세부항 
목인 입소자의 확보가 용이해짐으로 제도에 대한 시설종사자들의 긍정적 인식이 나타났으며, 둘째, 서비스의 질 관리가 제도 시행 전보다 더 잘되어 짐으로 셋째, 장기요양서비스의 질 수준이 높아졌 기 때문인 것으로 나타났다. 특히 서비스관리영역 은 소규모시설 즉 개인시설 일 때 좀 더 긍정적 인식을 나타내는 것으로 조사되었다. 이것은 제도 시행 전 국가 지원을 받지 못했던 소규모 시설이 요양급여를 받으면서 재정이 건실해 짐으로 프로 그램을 다양화 하고 서비스에 질을 높이기 위해 노력을 함에 의한 결과로 볼 수 있다.

또한 본 연구에서는 인사관리영역에서의 운영환 경변화에 따른 인식이 요양보호사 확보 및 업무 전문성에서 긍정적인 경향을 나타냈지만, 현실적으 로 서비스를 전달하는 요양보호사의 전문성에 관 한 문제점을 제기한 연구도 있다. 현재 요양보호사 는 민간시설에서 시간이수제로 자격을 취득하고 있으며 제도 시행 초기 단계에 필요한 요양보호사 의 수를 채우기에 급급해 제대로 된 교육을 받지 못한 요양보호사가 적잖게 많다. 많은 시설에서 이 부분에 대한 문제를 않고 있으며 시설 자체내에서 해결은 한계점이 있으며 국가차원의 방안이 요구 되어진다.

이와 같은 요양보호사의 전문성 문제는, 기존의 연구에서 미국의 노인장기요양보험제도 체계의 운 영 경험을 통해 얻어진 여러 가지 개선 방안들 중 의 한 가지로, 시설요양서비스의 질적 수준을 관 리·감독할 수 있는 분명한 근거를 마련함과 동시 에 미국의 경우와 마찬가지로 그것을 꾸준히 수 정·보완하면서 시설요양서비스의 질적 수준 향상 을 꾀하여 소비자의 옥구를 충족시킬 필요가 있다 고 한 것과도 일맥상통하는 것으로 볼 수 있다 [10].

본 연구자는 본 연구결과와 관련하여 장기요양 인력의 질이 서비스 질과 바로 직결된다는 측면에 서 요양보호사의 질적인 자격관리를 어떻게 할 것
인가는 매우 중요한 문제라 여겨짐에 따라 요양서 비스 질 수준을 높이기 위해 노인복지법 개정을 통해 요양보호사 양성 및 자격관리체계를 전면적 으로 수정해야하며 구체적으로는 요양보호사 양성 기관에 대한 인증 제도를 도입하고, 요양보호사 자 격관리를 강화하여 신규 인력에 대해서는 보다 확 충-강화된 교육을 도입하여야 할 것이다. 그리고 공공성과 장기요양 인력의 질 관리가 이루어질 수 있도록 국가가 관장하는 연수체계를 구축하여 현 장 실무자에 대한 정기적인 연수 기회를 제공하고 새로운 기술-지식의 습득과 윤리의식 강화를 도 모해야 한다. 또한 장기요양인력의 보수교육체계와 서비스 질 관리를 위한 모니터링과 평가체계도 구 축해야 한다고 생각된다.

이와 관련된 기존의 연구 결과[11]에도 나타나 있듯이, 현행제도의 표준장기요양이용계획서를 통 해서 지원하고 있는 서비스 이용 방식이 서비스이 용자가 적합한 서비스를 서비스기관으로부터 적절 한 양 만큼 이용할 수 있도록 판단, 결정하는 데에 별로 도움을 주고 있지 못하여 활용도가 그다지 높지 않다는 이유 때문에, 지역사회 내에 보건·의 료·복지서비스를 포괄적으로 조정·연계할 수 있 는 기능을 지닌 장기요양코디네이터의 구축이 필 요하다고 하였다.

둘째, 지속가능한 제도의 안정화를 위해서는 재 정적 부담에 대한 사회적 합의가 있어야 할 것이 다. 회귀분석결과, 재무회계관리 영역에서 긍정적 인식이 높을수록 전반적 인식에 긍정적 영향을 주 는 것으로 나타났다. 그러나 운영규모와 운영주체 에 따른 재무회계영역 차이검증에서 작은 운영규 모에서 그리고 개인 시설이 긍정적 인식을 하는 것으로 조사되었다. 이는 규모가 50 인 이상 되는 큰 시설은 대부분 법인시설로 노인복지법개정 이 전에 시설운영비, 인건비를 지원받던 부분이 노인 복지법 개정 이후 청구되어진 요양급여로만 시설 을 운영함에 있어 나타난 결과로 보인다. 규모가 
작은 기관은 운영비의 충분 현상이 일어나고 규모 가 큰 시설은 운영비의 부족 현상이 일어나고 있 다. 이로 인해 규모가 큰 시설에서 나타날 몇 가지 문제점은 불필요한 급여 서비스와 비급여 부분을 증가시켜 부족분을 채우고자 하거나 노인요양시설 이 밀집한 지역에서 시설입소자의 등급을 무리하 게 상향 유지하려는 노력이 있을 것이라 예상되어 진다.

이는 현재 요양보호제도를 시행하고 있는 대부 분의 국가들이 재정 문제에 직면하고 있으며, 특히 우리나라는 노인 인구의 증가속도가 다른 나라보 다 훨씬 더 빠르다는 문제로 인하여 재정의 안정 성 확보가 가장 중요한 과제이며 이를 해결하기 위하여 재원 마련을 위한 구체적인 방안들이 모색 되어야 한다고 기존의 연구 결과에서도 제시된 바 있다[12].

\section{$\mathrm{V}$. 결론}

본 논문은 노인장기요양보험제도의 실시에 따라 시설종사자의 노인장기요양보험에 관한 전반적 인 식과 영역별 운영환경변화 인식과의 상관관계와 영향을 미치는 변수를 살펴보았으며 결과를 정리 하면 다음과 같다.

첫 번째 연구문제인 일반적 특성에 따른 영역별 노인요양시설 운영환경변화 인식과, 두 번째 연구 문제인 일반적 특성에 따른 전반적 인식의 영향을 살펴본 결과, 운영규모에 있어서 규모가 큰 기관에 비해 작은 기관이 제도 시행에 있어서 긍정적 인 식을 가지는 것으로 나타났고, 운영주체는 법인에 비해 개인운영이, 직책에 있어서는 직급이 높을 수 록 긍정적 인식을 보이는 것으로 조사되었다.

세 번째 연구문제인 노인장기요양보험 실시의 영역별 운영환경변화 인식이 전반적 인식에 미치 는 영향을 분석한 결과, 서비스관리영역, 개인시설 일 경우, 재무회계영역 순으로 영향을 미치고 있는
것으로 나타났으며, 운영규모, 인사관리영역, 시설 관리영역, 정보관리 및 기타영역은 전반적 인식에 영향을 미치지 않는 것으로 나타났다.

본 연구자는 조사 결과에 따라 큰 시설들이 재 정부족에서 야기되는 문제를 다음과 같이 제안함 으로 제도의 안정적 정착에 기여하고자 한다. 첫째 는, 후원금제도의 활성화이다. 현재 정부에서는 소 득세법 제 34 조에 따라 개인이 시설에 후원한 금 액은 기부금의 형태로 소득공제를 해주고 있다. 이 를 이용한 후원금 활성화가 필요하다고 생각되어 지는데 개인 및 법인 시설이 요양급여로 채워지는 시설 재정의 한계를 후원금 활성화를 통해 재정을 채움으로 운영의 안정화를 기대할 수 있을 거라 예상된다. 따라서 후원금 활성화의 국민적 홍보가 필요하고 노인요양시설은 후원 프로그램을 만들고 정부에서는 이를 홍보하여 후원금을 장려하고 적 극적인 활성화를 통하여 시설의 재정 부담을 줄이 는 것이 필요하며 부족한 인력에 대한 자원봉사자 의 적극적 활용으로 시설을 다녀가는 이들에게 만 족감을 심어주어 그들을 통해 자연스럽게 시설에 대한 구전마케팅이 이루어지게 하는 전략적 계획 이 필요하다.

본 연구를 토대로 후속 연구과제로는 운영규모 에 따라 시설을 운영할 수 있는 운영모형계발과 요양서비스 질을 높이기 위한 방안에 대한 연구가 필요할 것이다.

\section{참고문헌}

1. 고령친화센터(2008), 2007년 고령친화산업 기초통 계, 한국보건산업진흥원, pp.86-95.

2. 경현욱(2007), 노인장기요양보험이 노인복지시설에 미치는 영향, 명지대학교 사회복지대학원 석사학 위논문, pp.19-56.

3. 한국보건사회연구원(2007), 노인 장기요양보험제도 
도입에 따른 노인요양시설의 경영전략개발 연구, pp.17-46.

4. 보건복지부(2008), 2008년 노인보건복지사업안내, pp.5-86.

5. 원미희(2007), 노인장기요양보험의 요양시설급여 및 재가급여 서비스 이용의사와 결정요인에 관한 노인세대 중년세대간 비교연구, 명지대학교 사회 복지대학원 석사학위논문, pp.5-13.

6. 박명선, 강상목(2010), 노인 장기요양 보험제도 실 시에 따른 전문직종사자의 수요 예측 -간호사, 사 회복지사, 요양보호사를 중심으로-, 한국통계학회 논문집, Vol.17(3);423-440.

7. 허창덕, 신주영, 양현일(2011), 장애인장기요양보장 제도의 방향성 연구, 재활복지, Vol.15(1);95-119.

8. 노형진, 정한열(2008), SPSS에 의한 통계분석 입문, 한올출판사, pp.45-89.

9. 강병서, 조철호(2006), 연구조사방법론, 무역경영사, pp.88-192.

10. 김나영(2010), 외국체계의 운영경험으로 본 노인 장기요양보험제도의 개선방안: 미국사례, 보건복지 포럼, Vol168;45-56.

11. 선우덕(2010), 정부 정책의 방향 설정을 위한 노 인장기요양보험제도의 개선방안, 보건복지포럼, Vol.168;16-24.

12. 조국행, 김동호(2010), 국가간 비교를 통한 노인 장기요양보험제도 개선방안, 21 세기사회복지연구, Vol.7(2);79-105.

접수일자 2011년 8월 18일 심사일자 2011년 8월 30일 게재확정일자 2011년 9월 11일 